\title{
Histomorphometry of the Testes and Epididymis in the Domesticated Adult African Great Cane Rat (Thryonomys swinderianus)
}

\author{
Histomorfometría del Testículo y el Epidídimo en la Gran Rata \\ Africana de la Caña Adulta Domesticada (Thryonomys swinderianus)
}

\author{
S. G. Olukole \& T. E. Obayemi
}

OLUKOLE, S. G. \& OBAYEMI, T. E. Histomorphometry of the testes and epididymis in the domesticated adult African great cane rat (Thryonomys swinderianus). Int. J. Morphol., 28(4):1251-1254, 2010.

SUMMARY: Histomorphometry of the testes and epididymis were carried out on the domesticated adult African great cane rat (Thryonomys swinderianus), also known as the grasscutter. The average weight and age of the cane rats used in the study were $1.93 \pm$ $0.42 \mathrm{~kg}$ and $18.80 \pm 1.39$ months respectively. The mean relative volume of the germinal epithelium, interstitium and lumen of the seminiferous tubules of the cane rats were $68.54 \pm 1.63 \%, 8.86 \pm 0.85 \%$ and $21.40 \pm 1.12 \%$ respectively. The mean diameter of the seminiferous tubules of the cane rats used for this study was $183.0 \pm 11.06 \mu \mathrm{m}$. The ductal diameter of the caput, corpus and cauda epididymis were $207.4 \pm 7.41 \mu \mathrm{m}, 237.8 \pm 10.15 \mu \mathrm{m}$ and $274.2 \pm 9.00 \mu \mathrm{m}$ respectively, being statistically different (p<0.05). The epididymal luminal diameters were $95.8 \pm 11.52 \mu \mathrm{m}, 126.8 \pm 8.35 \mu \mathrm{m}$ and $221.0 \pm 4.05 \mu \mathrm{m}$, respectively for the caput, corpus and cauda epididymis. The caput, corpus and cauda epididymis had epithelial heights of $63.6 \pm 2.23 \mu \mathrm{m}, 59.20 \pm 3.38 \mu \mathrm{m}$ and $28.60 \pm 9.23 \mu \mathrm{m}$ respectively. There was a high negative correlation (-0.7958) between epithelial height and lumen diameter meaning that with a decrease in the height of the epithelium, the lumen increased significantly. This research work provides base-line data on the histomorphometry of the testes and epididymis of the African great cane rat (Thryonomys swinderianus).

KEY WORDS: Testes; Epididymis; Tubular diameter; Cane rat; Morphometry.

\section{INTRODUCTION}

It is very evident in Nigeria today that the average citizen does not meet the protein requirements for humans. This is seen from data obtained for alternative source of animal protein to augment the shortage currently existing in conventional livestock (Chupin, 1992). Wildlife domestication has been recognized as a possible way of achieving this objective (Ajayi, 1971). The grasscutter (Thryonomys swinderianus), also known as the African great cane rat, is a wild hystricomorphic rodent widely distributed in the African sub-region and exploited in most areas as a source of animal protein (NRC, 1991). Among the wild rodents found in the African subregion, the grasscutter or cane rat is the most preferred (Asibey \& Eyeson, 1975; Clottey, 1981). Being the most preferred bush meat in West Africa, including Nigeria, Togo, Benin, Ghana and Cote' d'Voire, it contributes to both local and export earnings of most West African countries and is therefore hunted aggressively (Baptist \& Mensah, 1986; Ntiamoa, 1988; Asibey \& Addo, 2000).

Reproductive organs are not unconditionally necessary for the individual life, but they have essential role in the reproduction and genesis of species. The great attention is given to morphology in relation to practice as well as to theoretical science (Abreu \& David-Ferreira, 1982; Kolodzieyski \& Danko, 1995; Akinloye et al., 2002). Reproductive organs represent the most dynamic organs in the animal as well as in human body. Great attention to study the reproductive organs has always been reported; particularly those of morphological structure and physiological functions of reproductive organs in many species (Pucek et al., 1993; Massányi et al., 2003). However, 
there are still many empty spaces mostly in wild animals especially in the area of morphometric studies.

The target of this study was to describe microscopic structure and to give exact morphometric values of the testes and epididymis of the adult domesticated grasscutter (Thryonomys swinderianus) with a view to providing baseline data on the subject area, which could facilitate an improved breeding of the animal in an effort to increase the sources of animal protein for consumption especially in rural communities.

\section{MATERIAL AND METHOD}

Experimental Animals. Twenty domesticated adult male cane rats were used for the study. They were acquired from a commercial farm in Igbesa, Ogun State, Nigeria. Records on the age and feeding patterns of the animals were also obtained from the farm. The cane rats were kept at the Animal House, Faculty of Veterinary Medicine, University of Ibadan for 72 hours. They were kept on a daily ration of Guinea corn offal of about $0.5 \mathrm{~kg}$ per body weight supplemented with raw cassava (Manihot species).

All the cane rats were weighed using a Microvar ${ }^{\circledR}$ weighing balance before being stunned and then slaughtered by cervical decapitation. Following this, each rat was placed on a dissection board on dorsal recumbency while a shallow medioventral incision was made from the linea alba to a point cranial to the anus in order to expose the abdominal and pelvic cavities. The testes and epididymides were carefully dissected out, with the latter separated into the caput, corpus and cauda regions on the basis of morphology. The weights of the testes and epididymides were determined using the Digital Microvar ${ }^{\circledR}$ weighing balance.

Histological procedures. The samples from the testes and epididymis were fixed in Bouin's fluid and embedded in paraffin blocks. Sections of $10 \mu \mathrm{m}$ thick were stained with Haematoxylin and Eosin (Akinloye et al.). The slides of testes and epididymis, were studied under the light microscope.

Histomorphometry. The slides were examined under the microscope and the following measurements were taken: the relative volume of the germinal epithelium, interstitium and lumen of the seminiferous tubules; the seminiferous tubular diameter, epididymal tubular diameter, epididymal luminal diameter and epididymal epithelial height. For each parameter, ten measurements were made per section using a calibrated eye-piece micrometer (Graticules Ltd. Toubridge Kent).
Statistical Analysis. All data obtained were expressed as means with the standard errors. Analysis of variance was performed using the One-way ANOVA while Duncan multiple range tests was used to compare means found to be statistically significant $(\mathrm{p}<0.05)$ using the GraphPad Prism version 4.00 for Windows, GraphPad Software (GraphPad Prism, 2003).

\section{RESULTS AND DISCUSSION}

The average weight of the cane rats used for the study was $1.93 \pm 0.42 \mathrm{~kg}$ with an average age of $18.80 \pm 1.39$ months. The testes of the cane rats were covered with stroma (tunica albuginea), consisting of collagenous tissue. Grossly, radially formed septa divided the testes into lobes (lobuli testes). The average size of the testes of the cane rats was $18.75 \times 11.33 \mathrm{~mm}$. There was a strong positive correlation $(r=0.8214)$ between the age of the rats and the weight of the testes and epididymis. However, there were a few exceptions where younger cane rats presented with bigger testes and epididymis than those from relatively older animals. The average percentage body weights for the testes and epididymis were $0.12 \%$ and $0.03 \%$ respectively. Microscopically, the testes of the rats showed seminiferous tubules having well formed germinal epithelium, which contained all cellular stages of spermatogenesis. The space between the tubules was filled with interstitial tissue, where various blood vessels and capillaries were observed.

The mean relative volume of the germinal epithelium, interstitium and lumen of the seminiferous tubules of the cane rats were $68.54 \pm 1.63 \%, 8.86 \pm 0.85 \%$ and $21.40 \pm 1.12 \%$ respectively (Table I). These values were similar to previous reports. In the rabbit, germinal epithelium constituted $77.6 \%$, interstitium $12.3 \%$ and lumen $10.0 \%$ of the testes while the value in the fallow-deer were $76.2 \%, 12.4 \%$ and $11.5 \%$ respectively for the germinal epithelium, interstitium and lumen (Mori \& Christenson, 1980; Massányi et al., 1999) In the testes of the fox, the germinal epithelium forms $52.7 \%$, interstitium $11.3 \%$ and lumen $36.0 \%$ while in the Sprague Dawley rat and ram, the values for the germinal epithelium were $82.4 \%$ and $70.5 \%$ respectively (Mori \& Christenson).

Table I. Mean and S.E.M. values of testicular histomorphometric parameters $(n=20)$. Means with the same superscript within the columns are statistically significant $(\mathrm{p}<0.05)$.

\begin{tabular}{lc} 
Germinal Epithelium (\%) & $68.54 \pm 1.63$ \\
Interstitium (\%) & $8.86 \pm 0.85^{\mathrm{a}}$ \\
Lumen (\%) & $21.40 \pm 1.12^{\mathrm{a}}$ \\
Diameter of Seminiferous Tubules $(\mu \mathrm{m})$ & $183.0 \pm 11.06$ \\
\hline
\end{tabular}


Table II. Mean and S.E.M. values of epididymal histomorphometric parameters $(n=20)$. Means with the same superscript within the rows are statistically significant $(\mathrm{p}<0.05)$.

\begin{tabular}{lccc}
\hline & Caput & Corpus & Cauda \\
\hline Ductal diameter $(\mu \mathrm{m})$ & $207.4 \pm 7.41^{\mathrm{a}}$ & $237.8 \pm 10.15^{\mathrm{a}}$ & $274.2 \pm 9.00^{\mathrm{a}}$ \\
Luminal diameter $(\mu \mathrm{m})$ & $95.8 \pm 11.52^{\mathrm{b}}$ & $126.8 \pm 8.35^{\mathrm{b}}$ & $221.0 \pm 4.05^{\mathrm{b}}$ \\
Epithelial height $(\mu \mathrm{m})$ & $63.6 \pm 2.23^{\mathrm{c}}$ & $59.20 \pm 3.38^{\mathrm{c}}$ & $28.60 \pm 9.23^{\mathrm{c}}$ \\
\hline
\end{tabular}

The mean diameter of the seminiferous tubules of the cane rats used for this study was $183.0 \pm 11.06 \mu \mathrm{m}$ (Table I). This value is higher than those of the rabbit and the fallowdear reported as $118.7 \mu \mathrm{m}$ and $143.1 \mu \mathrm{m}$ respectively (Mori \& Christenson; Massányi et al., 1999). Nevertheless, it is less than the diameter of seminiferous tubules in the African giant rat (Cricetomys gambianus, Waterhouse) reported as 212.85 $\pm 8.32 \mu \mathrm{m}$ (Oke, 1982). Also, the value of the diameter of seminiferous tubules obtained in the cane rats used in this study is lower than those of the male fox and Wister rat being 281.4 $\pm 30.5 \mu \mathrm{m}$ and $227.91 \pm 12.7 \mu \mathrm{m}$ respectively.

Microscopic analysis of the epididymis of the animals in this study showed that it was lined by pseudostratified columnar epithelium with stereocilia. This is in conformity with earlier reports on the histology of the epididymis of mammals (Oke). Like that of the seminiferous tubules, the epididymal ducts had spaces between the tubules and were filled with interstitial tissue. Mature spermatozoa were found more in the cauda epididymis than in the corpus epididymis but rarely in the caput epididymis. This is in conformity with earlier reports that sperm concentration was highest in the cauda epididymis of mammals (Dyce et al., 2002)

The mean values of ductal diameter, lumen diameter and epithelial height of the different segments of the epididymis of the cane rats used in this study are given in Table 2. The ductal diameter of the caput, corpus and cauda epididymis were $207.4 \pm 7.41 \mu \mathrm{m}, 237.8 \pm 10.15 \mu \mathrm{m}$ and $274.2 \pm 9.00$ $\mu \mathrm{m}$ respectively, being statistically different $(\mathrm{p}<0.05)$. These values are similar to earlier reports. The ductal diameter of the cauda epididymis of the African giant rat was reported to vary between $216.45 \mu \mathrm{m}$ and $242.82 \mu \mathrm{m}$ while that of the male fox was $352.3 \pm 46.10 \mu \mathrm{m}$ (Blom, 1968). There was a relatively high positive correlation $(0.6835)$ between the ductal diameters of the caput and cauda epididymis meaning that an increase in one of these parameters would result in an increase in the other. The pattern of the dimensions of the luminal diameter across the three segments of the epididymis was not different from that of the ductal diameter being $95.8 \pm 11.52$ $\mu \mathrm{m}, 126.8 \pm 8.35 \mu \mathrm{m}$ and $221.0 \pm 4.05 \mu \mathrm{m}$ respectively for the caput, corpus and cauda epididymis. A significant difference $(p<0.05)$ was observed with these values. However, the pattern of the dimensions of the epithelial height across the three segments of the epididymis was different from those of the ductal and lumen diameter. The caput, corpus and cauda epididymis had epithelial heights of $63.6 \pm 2.23 \mu \mathrm{m}, 59.20 \pm$ $3.38 \mu \mathrm{m}$ and $28.60 \pm 9.23 \mu \mathrm{m}$ respectively.

There was a low positive correlation (0.0420) between the diameter of the tubule of the epididymis and its epithelial height; this means that with an increase in epithelial height the increase in tubular diameter is low. There was a high negative correlation $(-0.7958)$ between epithelial height and lumen diameter meaning that with a decrease in the height of the epithelium, the lumen increased significantly. This relationship can be attributed to function rather than structure as the cauda epididymis has the widest lumen since it stores spermatozoa. This explains why more spermatozoa mass were found in the cauda then in the corpus epididymis in the cane rats used for this study.

However, it can be deduced from the findings of this work that the diameter of the seminiferous tubules, relative of the lumen and germinal epithelium of the testes as well as epididymal ductal diameter, lumen diameter and epithelial height are very similar in most mammals. The outcome of this research, therefore, provides base-line data on the histomorphometry of the testes and epididymis of the African great cane rat (Thryonomys swinderianus).

OLUKOLE, S. G. \& OBAYEMI, T. E. Histomorfometría del testículo y el epidídimo en la gran rata africana de la caña adulta domesticada (Thryonomys swinderianus). Int. J. Morphol., 28(4):12511254, 2010.

RESUMEN: Fueron realizados exámenes histomorfo-métricos de los testículos y del epidídimo en la gran rata africana adulta de caña demética (Thryonomys swinderianus), también conocido como grasscutter. El promedio del peso y de la edad de las ratas de caña fueron $1,93 \pm 0,42 \mathrm{~kg}$ y $18,80 \pm 1,39$ meses, respectivamente. El volumen relativo del epitelio germinal, intersticio y lumen de los túbulosseminíferos de las ratas de caña fueron $68,54 \pm 1,63 \%$, $8,86 \pm 0,85 \%$ y $21,40 \pm 1,12 \%$, respectivamente. El diámetro de los túbulos seminíferos fue 183,0 $\pm 11,06 \mu \mathrm{M}$. El diámetro ductal de la cabeza, cuerpo y cola del epidídimo fue $207,4 \pm 7,41 \mu \mathrm{M}, 237,8 \pm 10,15$ $\mu \mathrm{M}$ y $274,2 \pm 9,00 \mu \mathrm{M}$, respectivamente, siendo estadísticamente diferentes $(\mathrm{p}<0,05)$. El diámetro luminal del epidídimo fue 95,8 $\pm 11,52$ $\mu \mathrm{M}, 126,8 \pm 8,35 \mu \mathrm{M}$ y $221,0 \pm 4,05 \mu \mathrm{M}$, respectivamente para la cabeza, cuerpo y cola. La cabeza, cuerpo y cola del epidídimo tuvieron alturas epiteliales de $63,6 \pm 2,23 \mu \mathrm{M}, 59,20 \pm 3,38 \mu \mathrm{M}$ y 28,60 $\pm 9,23 \mu \mathrm{M}$, respectivamente. Hubo una alta correlación negativa (- 
0,7958) entre la altura epitelial y el diámetro del lumen, lo que significa que con una disminución en la altura del epitelio, el lumen aumentó apreciablemente. Este trabajo proporciona una base de datos histomorfométricos de los testículos y el epidídimo de la gran rata africana de caña (Thryonomys swinderianus).

PALABRAS CLAVE: Testículo; Epidídimo; Diámetro tubular; Rata de caña; Morfometría.

\section{REFERENCES}

Abreu, I. \& David-Ferreira, J. F. Fine structure of seminiferous tubules from prenatally irradiated rats. Cell Tissue Res., 222:143-52, 1982.

Ajayi, S. S. Wildlife as a source of protein in Nigeria: Some priorities for development. The Nigerian Field, 36:11523, 1971

Akinloye A. K.; Abatan, M. O.; Alaka, O. O. \& Oke, B. O. Histomorphometric and histopathological studies on the effect of Calotropis procera (giant milkweed) on the male reproductive organs of wistar rats. Afr. J. Biomed. Res., 5:57-61, 2002.

Asibey, E. O. A \& Addo, P. G. The grasscutter, a promising animal for meat production. In: Africa perspective practices and policies supporting sustainable development. Turnham, D. (ed.). Weaver Press, Zimbabwe, 2000. pp.2345.

Asibey, E. O. A. \& Eyeson, K. K. Additional information on the importance of wild animals as a food source in Africa South of Sahara. J. Ghana Wildlife Soc. Bongo, 1:13-7, 1975 .

Baptist, R. \& Mensah, G. A. The cane rat, farm animal of the future. World Anim. Rev., 60:12-8, 1986.

Blom, E. Male reproductive organs. In: Hafez, E. S. (Ed.). Reproduction in Farm Animals. Lea \& Febiger, Philadelphia, 1968. pp. 27-37.

Chupin, D. Needs for improvement of animal production in developing countries. In: Potentials and limitations of biotechnology in livestock production in developing countries. Niemann, H.; Franzen, H.; Smidt, D. \& Schwartz, H. J. (eds.). Germany, Marien, 1992. pp.2-55.

Clottey, J. A. Relation of body composition to meat yield in grasscutter (Thryonomis swinderianus Temminck). Ghana J. Sci., (21):1-7, 1981.
Dyce, K. M.; Sack, W. O. \& Wensing, C. J. C. Textbook of Veterinary Anatomy. $2^{\text {nd }}$ ed. W. B. London, Saunders, 2002. pp.158-62.

GraphPad Prism. Version 4.00 for windows. GraphPad Software, San Diego, California, USA. 2004.

Kolodzieyski, L. \& Danko, J. A histological, histochemical and immunohistochemical picture of the ovary of a hermaphrodite goat. Folia Vet., 39:107-10, 1995.

Massányi, P.; Janc`ová, A. \& Uhrín, V. Morphometric study of male reproductive organs in the rodent species Apodemus sylvaticus and Apodemus flavicollis. Bull. Vet. Inst. Pulway, 47:133-8, 2003.

Massányi, P.; Lukac, N.; Hluchy, S.; Slamecka, J.; Jurcik, R.; Toman, R. \& Kovacik, J. Seasonal variations in the metric analysis of the testes and epididymis in fallow-deer (Dama dama). Folia Vet., 43:67-70, 1999.

Mori, H. \& Christenson, A. K. Morphometric analysis of Leydig cells in the normal rat testes. J. Cell. Biol., 84: 340-54, 1980.

National Research Council. (NRC) Microlivestock: Little known small animals with promising economic future. Washington D.C., National Academy Press, 1991. pp.449.

Ntiamoa, B. Y. Sustainable use of bush meat in wildlife development plan. W. Devt. Acr., 6:74-8, 1988.

Oke, B. O. Some studies on the reproductive organs of the African giant rat (Cricetomys gambianus, Waterhouse) during the climatic seasons at Ibadan. M.Sc. thesis, Department of Veterinary Anatomy, University of Ibadan, Nigeria, 1982.

Pucek, Z.; Jedrzejewski, W.; Jedrzejewska, B. \& Pucek, M. Rodent population-Dynamics in a primeval deciduous forest (Bialowieza - National-Park) in relation to weather, seed crop, and predation. Acta Therio., 38:199-232, 1993.

Correspondence to:

Dr. Olukole S. G.

Department of Veterinary Anatomy

Faculty of Veterinary Medicine

University of Ibadan

NIGERIA

E-mail: deborolukole@yahoo.com sg.olukole@mail.ui.edu.ng

Received: 21-09-2009

Accepted: 25-05-2010 